\title{
Production and Marketing Challenges of Potato Cultivation in Haryana, India
}

\author{
Ashu $^{1}$, Dalip Kumar Bishnoi ${ }^{1}$, Jitender Kumar Bhatia ${ }^{1}$, Baskaur ${ }^{2}$ and O.P. Sheoran ${ }^{3}$ \\ ${ }^{1}$ Department of Agricultural Economics, CCSHAU, Hisar, Haryana, India \\ ${ }^{2}$ Department of Sociology, CCSHAU, Hisar, Haryana, India \\ ${ }^{3}$ Department of Math, Stat and Physics, CCSHAU, Hisar, Haryana, India \\ *Corresponding author
}

\begin{tabular}{l} 
K e y w o r d s \\
$\begin{array}{l}\text { Contract farming, } \\
\text { Predetermined } \\
\text { prices, Price } \\
\text { stability and firms }\end{array}$ \\
Article Info \\
$\begin{array}{l}\text { Accepted: } \\
12 \text { February } 2018 \\
\text { Available Online: } \\
10 \text { March } 2018\end{array}$ \\
\hline
\end{tabular}

\section{Introduction}

Contract farming is an agreement between farmers and processing and marketing firms for the production and supply of agricultural products under certain agreement, frequently at predetermined prices. In return, the firms are offered high price to the farmers against their farm produce. The basis of the relationship between the parties is a commitment on the part of the farmer to provide a specific commodity in quantities and in quality standards determined by the purchaser and an undertaking of the sponsor to support farmers' production and to purchase the commodity (Ahmad and Awais, 2011).

Potato is the most important food crop of the world. Potato is a crop which has always been the poor mans' crop. Potato is being cultivated in the country for the last more than 300 years. For vegetable purposes it has become one of the most popular crops in the country. Potato is a wholesome food which is rich in carbohydrates, proteins, minerals and vitamins. It is a rich source of potassium and 
very good for patients suffering from heart ailments. It contains 22.6 per cent carbohydrates, 1.6 per cent protein, 0.1 per cent fat, 0.4 per cent crude fibre and 97 (k cal) calories (National Horticulture Board). Potato is used for several industrial purposes such as for the production of starch and alcohol etc. Potato starch (farina) is used in laundries and for sizing yarn in textile mills. Potato is also used for the production of dextrin and glucose. Keeping in view the shrinking cultivable land and burgeoning population in India, potato is a better alternative to deal with the rising food demand.

India ranks $3^{\text {rd }}$ in area and $2^{\text {nd }}$ in production in the world after China. At world level, about 365.36 million tonnes of potato is produced. This production is obtained over an area of about 19.28 million hectare. The major potato growing countries in the world are China, Russia, India, USA, Germany, Poland, Ukraine, U.K., Turkey, Iran, Netherlands, France, New Zealand and Belgium. New Zealand occupied first rank in production of potato with 50.14 tonnes per hectare followed by USA (45.82 t/ha) and Belgium (45.42 t/ha) (National Horticultural Research and Development Foundation).

India had achieved approximately 43.42 million tonnes of production within a limited area of 2.12 million hectare during the year 2015-16. Maximum potato production takes place in Uttar Pradesh (13.85 million tonnes) followed by West Bengal (8.43 million tonnes), Bihar (6.34 million tonnes), Gujarat (3.55 million tonnes), Madhya Pradesh (3.16 million tonnes), Punjab (2.38 million tonnes), Assam (1.04 million tonnes), Haryana (0.85 million tonnes) and Chhattisgarh (0.64 million tonnes) respectively. Productivity is highest in Gujarat (31.58 t/ha) followed by Punjab (25.83 t/ha), Haryana (24.91 t/ha), Uttar Pradesh (22.81 t/ha), Madhya Pradesh (22.41 t/ha) and Maharashtra (20.12 t/ha). Uttar
Pradesh has highest share both in area 6.07 lakh hectare $(28.67 \%)$ and production 13.85 million tonnes $(31.90 \%)$. Total area under potato cultivation estimated around 1.24 per cent (21.17 lakh/ha.) more as compared to last year's area of 20.75 lakh ha. Total production of potato in the current year estimated less by around 1.11 per cent i.e. 43.42 million tonnes as compared to last year's production of 48.01 million tonnes. India and China even being a major potato producing countries has quite low productivity of $21.75 \mathrm{t} / \mathrm{ha}$ and $16.12 \mathrm{t} / \mathrm{ha}$ respectively.

The area, production and productivity of potato in Haryana were 34.27 thousand hectare, 853.80 thousand tonnes and 24.38 tonnes per hectare respectively during the year 2015-16. In Haryana, potato has got a prominent place and holds the first position among the other vegetable crops with respect to area and production under different vegetables. In Haryana, it is grown mainly in the districts like Kurukshtera, Yamunanagar, Karnal, Sonipat, Ambala, Panchkula, Panipat, Rohtak, Jind and Sirsa (Directorate of Horticulture Research, 2015-16).

The contract farming is emerging as an important tool for reducing risk in crop production and minimizing price uncertainty of the produce. As it is a new mechanism in Indian agriculture, it needs to be studied in detail whether involvement of the corporate sector in agriculture is beneficial to the producers/farmers. Thus the study was planned and undertaken in Haryana

\section{Materials and Methods}

The study was undertaken in Karnal district of Haryana keeping in view the highest area under potato contract farming. From the selected district, Gharaunda and Indri blocks having the largest area under the potato cultivation were selected for the study. Three 
villages were selected from each block having highest area under contract farming and noncontract farming. These villages were Arrainpura, Bassi Akbarpur and Faridpur in Gharaunda block whereas Khanpur, Jainpur and Phoosgarh from Indri block in Karnal district. Total 90 farmers were selected randomly comprising of 45 each for contract and non-contract potato growers from the Karnal district. The tabular form of analysis was adopted to analyze opinion of farmers regarding the problems in production and marketing. The tabulation was made separately for categories of contract and noncontract farmers.

\section{Results and Discussion}

\section{Socio-economic profiles of the respondents}

Socio-economic status of the selected respondents are presented in Table 1. In a group of 45 contract farming families there were a total of 283 family members. Among these, percentage of adult males, adult females, children males \& children females were 39.57, 29.41, 20.85 and 14.84, respectively. Similarly, the total number of family members in a group of 45 non-contact farming families were 298 and among them adult males, adult females, children male \& females were 38.44, 24.10, 21.82 and 13.09 per cent, respectively. As far as educational status of the selected respondents was concerned, more than ninety per cent were found literate, whereas only 7.78 per cent were illiterate.

Among literate, more than sixty per cent potato grower were educated up to secondary level followed by senior secondary and graduate i.e. 25.55 and 5.55 per cents respectively, it was clearly indicated from table that among the selected respondents, more than sixty per cent respondents were falling in between the age group of 38-55 years, followed by young age and old age group i.e. 18.89 and 16.67 per cent, respectively.

Problem related to production and marketing of potato seed production

In order to elicit the problems with respect to the various aspects of potato seed production and marketing were identified:

Production related problems faced by the respondents

A comprehensive feedback of farmers has been mentioned in Table 2. High susceptibility towards insect-pests and disease such as aphid insect, black spot and bacterial blight disease were identified as the most common and major problem for both contract $(73.33 \%)$ and non-contract farmers $(77.78 \%)$. Unlike above cited problem the number of contract farmers (68.89\%) who were facing the problem of oversized tubers was high as compared to noncontract farmers $(64.44 \%)$.

The higher cost of inputs were expressed by 77.78 per cent of contract farmers whereas 55.55 per cent by non-contract farmers. Further, timely and non-availability of labourers during digging seasons was also reported as a general problem among both contract $(73.33 \%)$ as well as non-contract farmers $(60 \%)$. Occurrence of unfavorable climatic conditions was reported by 75.56 per cent and 77.78 per cent of contract and noncontract farmers respectively. Similar results were observed by Singh (2000), Malik (2013), and Rampal (2013) in their respective studies.

Marketing related problems faced by the respondents

A comprehensive view on the marketing related problems has been elucidated in Table 3. 
Table.1 Family composition of respondents in Karnal district of Haryana

(1) Family composition of respondents

\begin{tabular}{|l|c|c|c|}
\hline Particular & Contract Farmers & Non-Contract Farmers & Overall Total \\
\hline Adult Male & $112(39.57)$ & $118(38.44)$ & $230(39.59)$ \\
\hline Adult Female & $70(29.41)$ & $74(24.10)$ & $144(24.78)$ \\
\hline Children (M) & $59(20.85)$ & $67(21.82)$ & $81(13.94)$ \\
\hline Children (F) & $42(14.84)$ & $39(13.09)$ & $581(100)$ \\
\hline Total & $283(100)$ & $298(100)$ & \\
\hline
\end{tabular}

(2) Distribution of respondents according to their education status

\begin{tabular}{|c|c|c|c|}
\hline Illiterate & $3(6.67)$ & $4(8.89)$ & $7(7.78)$ \\
\hline Up to secondary & $28(62.22)$ & $27(60)$ & $55(61.11)$ \\
\hline Up to Senior Secondary & $12(26.67)$ & $11(24.44)$ & $23(25.55)$ \\
\hline Graduate & $2(4.44)$ & $3(6.67)$ & $5(5.55)$ \\
\hline Total & $45(100)$ & $45(100)$ & $90(100)$ \\
\hline
\end{tabular}

(3) Distribution of respondents according to their age group

\begin{tabular}{|l|c|c|c|}
\hline Young (Up to 37) & $8(17.78)$ & $9(20)$ & $17(18.89)$ \\
\hline Middle (38-55) & $28(62.22)$ & $30(66.67)$ & $58(64.44)$ \\
\hline Old (above 55) & $9(20)$ & $6(13.33)$ & $15(16.67)$ \\
\hline Total & $45(100)$ & $45(100)$ & $90(100)$ \\
\hline
\end{tabular}

Note: Figures in parentheses indicate the percentage to the sample size 
Table.2 Constraints of potato seed production in Karnal district of Haryana

\begin{tabular}{|c|c|c|c|c|c|c|c|c|c|}
\hline \multirow{2}{*}{$\begin{array}{l}\text { Sr. } \\
\text { no. }\end{array}$} & \multirow[t]{2}{*}{ Production related problems } & \multicolumn{4}{|c|}{ Contract - farmers $(n=45)$} & \multicolumn{4}{|c|}{ Non - contract farmers $(n=45)$} \\
\hline & & Small & Medium & Large & Overall & Small & Medium & Large & Overall \\
\hline 1 & $\begin{array}{l}\text { Highly sensitive to insect-pest \& } \\
\text { diseases infestation }\end{array}$ & $19(73.08)$ & $\begin{array}{c}10 \\
(83.33)\end{array}$ & $4(57.14)$ & $33(73.33)$ & $20(83.33)$ & $\begin{array}{c}9 \\
(75.00)\end{array}$ & $6(66.67)$ & $35(77.78)$ \\
\hline 2 & $\begin{array}{l}\text { Problem of oversized tubers during } \\
\text { seed production }\end{array}$ & $18(69.23)$ & $8(66.67)$ & $5(71.43)$ & $31(68.89)$ & $16(66.67)$ & $8(66.67)$ & $5(55.56)$ & $29(64.44)$ \\
\hline 3 & $\begin{array}{c}\text { Higher cost of inputs in potato seed } \\
\text { cultivation }\end{array}$ & $19(73.08)$ & $10(83.33)$ & $6(85.71)$ & $35(77.78)$ & $15(62.50)$ & $\begin{array}{c}7 \\
(58.33)\end{array}$ & $3(33.33)$ & $25(55.55)$ \\
\hline 4 & $\begin{array}{l}\text { Timely \& adequately availability of } \\
\text { labourers in Digging seasons }\end{array}$ & $20(76.92)$ & $\begin{array}{c}10 \\
(83.33)\end{array}$ & $3(42.86)$ & $33(73.33)$ & $17(70.83)$ & $6(50.00)$ & $4(44.44)$ & $27(60.00)$ \\
\hline 5 & $\begin{array}{l}\text { Highly sensitive crop to } \\
\text { environmental variable like } \\
\text { moisture, temperature etc. }\end{array}$ & $21(80.77)$ & $7(58.33)$ & $6(85.71)$ & $34(75.56)$ & $20(83.33)$ & $8(66.67)$ & $7(77.78)$ & $35(77.78)$ \\
\hline
\end{tabular}

Table.3 Constraints of potato seed marketing in Karnal district of Haryana

\begin{tabular}{|c|c|c|c|c|c|c|c|c|c|}
\hline \multirow[t]{2}{*}{ Sr. no. } & \multirow[t]{2}{*}{ Marketing related problem } & \multicolumn{4}{|c|}{ Contract farmers $(n=45)$} & \multicolumn{4}{|c|}{ Non - contract farmers $(n=45)$} \\
\hline & & Small & Medium & Large & Overall & Small & Medium & Large & Overall \\
\hline 1 & Cut in weight of produce & $\begin{array}{c}14 \\
(53.85)\end{array}$ & $6(50.00)$ & $\begin{array}{c}4 \\
(57.14)\end{array}$ & $24(53.33)$ & - & - & - & - \\
\hline 2 & Rejection of produce & $\begin{array}{c}10 \\
(38.46)\end{array}$ & $4(33.33)$ & $\begin{array}{c}3 \\
(42.86)\end{array}$ & $17(37.78)$ & - & - & - & - \\
\hline 3 & Higher transportation cost & - & - & - & - & $11(45.83)$ & $5(41.67)$ & $5(55.56)$ & $\begin{array}{c}21 \\
(46.67)\end{array}$ \\
\hline 4 & Lower price of produce & $7(26.92)$ & $3(25.00)$ & $\begin{array}{c}2 \\
(25.00)\end{array}$ & $12(26.67)$ & $19(79.19)$ & $9(75.00)$ & $6(66.67)$ & $\begin{array}{c}34 \\
(75.56)\end{array}$ \\
\hline 5 & High storage charges & - & - & - & - & $12(50.00)$ & $7(58.33)$ & $4(44.44)$ & $\begin{array}{c}23 \\
(51.11)\end{array}$ \\
\hline 6 & Lack of credit facilities & $\begin{array}{c}11 \\
(42.31)\end{array}$ & $5(41.67)$ & $\begin{array}{c}2 \\
(28.57)\end{array}$ & $18(40.00)$ & $13(54.17)$ & $7(58.33)$ & $3(33.33)$ & $\begin{array}{c}23 \\
(51.11)\end{array}$ \\
\hline 7 & Lack of proper marketing facilities & - & - & - & - & $15(62.50)$ & $6(50.00)$ & $5(55.56)$ & $\begin{array}{c}26 \\
(57.78)\end{array}$ \\
\hline 8 & High marketing cost & - & - & - & - & $18(75.00)$ & $8(66.67)$ & $6(66.67)$ & $\begin{array}{c}32 \\
(71.11)\end{array}$ \\
\hline
\end{tabular}


More than thirty seven per cent contract farmers faced the problem of rejection of their produce. More than 46.67 per cent of noncontract farmers were opinioned about the higher expenditure in transiting their produce to market. Whereas in case of contract farming the transportation cost is paid by the contract company (Rs.25/qtl up to $50 \mathrm{~km}$ and Rs.35/qtl beyond $50 \mathrm{~km}$ ). Further, both the contract as well as non-contract farmers did not show any problem about the delayed payment by the company and wholesaler respectively for their produces. As far as level of satisfaction of potato prices was concerned, more than 75 per cent of contract farmers were satisfied about the prices of potato seed whereas only 26.67 per cent non-contract farmers were satisfied about the prices of their produce.

Lack of credit facilities were also observed as a major problem both in case of contract $(40 \%)$ as well as non-contract farmers $(51.11 \%)$. Whereas only non-contract farmers' were faced the problem of lack of marketing facilities and high marketing cost i.e. 57.78 per cent and 71.11 per cent respectively. Similar results were reported by Buvaneshwaran and Banumathy (2008) in their respective studies.

\section{Feedback given by farmers}

When questions were asked from the contract and non- farmers regarding the prospects of potato seed production. The results revealed that more than 59.38 percent of the contract farmers were willing to increase the area under potato seed production, while 40.62 percent of the contract farmers were willing to keep the area constant under potato seed production. On the other hand, in case of noncontract farmers the result almost opposite to contract farmers i.e. 44.65 per cent noncontract farmers were willing to increase area under potato seed production.
While 55.35 per cent farmers were not agreed to increase area under potato seed production. When another question asked from the contract farmers if they wish to go for contract farming in other crops, an overwhelming response was reported. The 64.59 per cent farmers were interested in contract farming especially with the crops like vegetables, rice, wheat and sugarcane only if the contractual agency provides them good quality seeds and other inputs with low cost. When the same question were asked to noncontract farmers it was reported that 45.73 per cent of the farmers were not at all interested in contract farming and 54.27 per cent were interested but they were not having any proper guidance/contacts with contract agencies.

The study was undertaken in Karnal district of Haryana. Further Gharaunda and Indri block were selected out of six blocks of Karnal District. In Gharaunda block three villages namely Arrainpura, Bassi Akbarpur, Faridpur whereas Khanpur, Jainpur and Phoosgarh were selected from Indri block in Karnal district. Total ninety farmers forty five each from contract as well as non-contract were interviewed for the study. The study revealed that high susceptibility towards insect-pests and disease such as aphid insect, black spot and bacterial blight disease were observed most common and major production problems for both contract $(73.33 \%)$ and non-contract farmers $(77.78 \%)$; however, less number of contact farmers were facing these problems. This was mainly due to a proper guidance about the various cultivation and management practices provided by the parent company field executive officers (FEO) during the potato seed production. Whereas cut weight of produce $(53.3 \%)$ rejection of produce $(37.78 \%)$ in case of contract farmers, lower price of produce $(75.56 \%)$, high marketing cost $(71.11 \%)$, lack of proper marketing facilities $(57.78 \%)$, high storage charges 
$(51.11 \%)$ in case of non-contract farmers, lack of credit facilities both in contract (40\%) as well as non-contract farmers (51.11 \%) were observed marketing related problems in the study area. In nutshell, the potato seed production was found to be profitable with the adoption of contract farming due to the remunerative price as well as proper guidance about the various cultivation and management practices provided by the parent companies' field executive officers (FEO) during the potato seed production which reduced yield and price uncertainty. Therefore, use of contract farming needs to be expanded among all the potato seed growers.

\section{References}

Ahmad, R. and Awais, M. (2011). Contract farming in India issues and challenges. Financing Agriculture, 43 (3):30-32.

Buvaneshwaran, P. and Banumathy, V. (2008). Economics of lilium production under contract farming in the Nilgiri district, Tamil Nadu. Agricultural Economics Research Review, 21: 434.

Directorate of Horticulture research, Panchkula (http://hortharyana.gov.in).

Malik, A. (2013). Contract farming: Pros and cons in Indian agriculture system. International Journal of Management, IT and Engineering, 3 (5): 220-234.

National Horticultural Research and Development Foundation, New Delhi (www.nhrdf.org.).

Rampal, V. K. (2013). Analytical study of contract farming system in Punjab. Journal of Community Mobilization and Sustainable Development, 8 (1): 78-83.

Singh, S. (2000). Contract farming for agricultural diversification in the Indian Punjab: A study of performance and Problems. Indian Journal of Agricultural Economics, 56 (3): 283294.

\section{How to cite this article:}

Ashu, Dalip Kumar Bishnoi, Jitender Kumar Bhatia, Baskaur and Sheoran, O.P. 2018. Production and Marketing Challenges of Potato Cultivation in Haryana, India. Int.J.Curr.Microbiol.App.Sci. 7(03): 1349-1355. doi: https://doi.org/10.20546/ijcmas.2018.703.161 